\title{
trans Fatty acids and systemic inflammation in heart failure
}

\section{Citation}

Mozaffarian, Dariush. 2006. 'Trans fatty acids - Effects on systemic inflammation and endothelial function.' Atherosclerosis Supplements 7, 2: 29-32. https://doi.org/10.1016/ j.atherosclerosissup.2006.04.007

\section{Permanent link}

http://nrs.harvard.edu/urn-3:HUL.InstRepos:41249197

\section{Terms of Use}

This article was downloaded from Harvard University's DASH repository, and is made available under the terms and conditions applicable to Other Posted Material, as set forth at http:// nrs.harvard.edu/urn-3:HUL.InstRepos:dash.current.terms-of-use\#LAA

\section{Share Your Story}

The Harvard community has made this article openly available.

Please share how this access benefits you. Submit a story.

Accessibility 
Published in final edited form as:

Am J Clin Nutr. 2004 December ; 80(6): 1521-1525.

\title{
trans Fatty acids and systemic inflammation in heart failure $1,2,3,4$
}

\author{
Dariush Mozaffarian, Eric B Rimm, Irena B King, Richard L Lawler, George B McDonald, and \\ Wayne C Levy
}

\begin{abstract}
Background: trans Fatty acid (TFA) intake increases systemic inflammation in healthy persons. However, the effect in patients with established heart disease is unknown.

Objective: Our aim was to determine whether TFAs are associated with systemic inflammation in patients with established heart disease.

Design: Red blood cell membrane TFAs, a biomarker of dietary intake, and inflammatory marker concentrations were ascertained in 86 ambulatory patients with established heart failure. Associations between TFA levels and inflammatory markers were evaluated by linear regression.
\end{abstract}

\begin{abstract}
Results: Mean ( \pm SD) TFA levels were $1.8 \pm 0.4 \%$ of membrane fatty acids (range: $0.7-2.9 \%)$. For each inflammatory marker, associations are presented as the absolute difference and percentage difference from the mean for each 1\% higher membrane TFA level. After adjustment for age, sex, body mass index, diabetes, smoking, ejection fraction, New York Heart Association class, ischemic etiology, statin use, and serum glucose, TFA levels were positively associated with interleukin (IL) $1 \beta$ (difference from mean: $0.38 \mathrm{pg} / \mathrm{mL}$; percentage difference from mean: $66 \% ; P=0.04$ ), IL-1 receptor antagonist ( $4033 \mathrm{pg} / \mathrm{mL} ; 297 \% ; P=0.006)$, IL-6 (9.5 pg/mL; 123\%; $P=0.006)$, IL-10 (241 $\mathrm{pg} / \mathrm{mL} ; 183 \% ; P=0.02)$, tumor necrosis factor $(\mathrm{TNF})=(256 \mathrm{pg} / \mathrm{mL} ; 249 \% ; P=0.02)$, TNF receptor $1(537 \mathrm{pg} / \mathrm{mL} ; 41 \% ; P=0.03)$, TNF receptor $2(39242 \mathrm{pg} / \mathrm{mL} ; 247 \% ; P=0.001)$, monocyte chemoattractant protein $1(117 \mathrm{pg} / \mathrm{mL} ; 119 \% ; P=0.004)$, and brain natriuretic peptide $(40 \mathrm{pg} / \mathrm{mL}$; $57 \% ; P=0.04)$. Further adjustments for other patient characteristics did not significantly alter the results.
\end{abstract}

Conclusion: TFAs are strongly associated with systemic inflammation in patients with heart disease, which suggests that attention to TFA intake may be important for secondary prevention efforts.

\section{Keywords}

Inflammation; trans fatty acids; heart failure; diet tumor necrosis factor; interleukin

\footnotetext{
${ }^{1}$ From the Channing Laboratory, Department of Medicine, Brigham and Women's Hospital and Harvard Medical School, and the Departments of Nutrition and Epidemiology, Harvard School of Public Health, Boston (DM and EBR); the Divisions of Public Health Sciences and Clinical Research, Fred Hutchinson Cancer Research Center, Seattle (IBK, RLL, and GBM); and the Division of Cardiology, University of Washington, Seattle (WCL).

${ }^{2}$ Abstract presented at the American Heart Association Conference on Cardiovascular Disease Epidemiology and Prevention, San Francisco, March 2004.

${ }^{3}$ Supported by a Charles A Dana Foundation grant, New York; the American Heart Association, Dallas; and the University of Washington Clinical Research Center, Seattle (NIH M01-RR-00037). GBM's Cytokine Analysis Laboratory was supported by the National Institutes of Health (CA18029). DM was supported in part by a National Research Service Award Training Grant in Academic Nutrition (DK07703).

${ }^{4}$ Address reprint requests to D Mozaffarian, 665 Huntington Avenue, Building 2, Room 315, Boston, MA 02115. E-mail: dmozaffa@hsph.harvard.edu.
} 


\section{INTRODUCTION}

trans Fatty acids (TFAs), unsaturated fats with at least one double bond in the trans configuration, are formed during the industrial hydrogenation of vegetable oils. TFAs are primarily consumed in fast foods, bakery products, packaged snacks, and margarines; smaller amounts are consumed in dairy products and meats (1). There is currently considerable interest in the potential health effects of TFAs, and the US Food and Drug Administration recently ruled that the TFA content be declared on the nutrition labels of all conventional foods and dietary supplements effective 1 January 2006 (2). A recent observational study (3) and shortterm randomized trial (4) indicated that TFA intake increases systemic inflammation in generally healthy persons. Because systemic inflammation is an independent risk factor for future heart disease (5), these findings suggest a novel potential mechanism whereby TFAs may affect the cardiovascular health of generally healthy persons.

Compared with healthy persons, patients with established heart disease often have much higher concentrations of systemic inflammation (6-8). Although TFAs appear to be proinflammatory in generally healthy persons $(3,4)$, it is unknown whether TFAs influence inflammation in patients with established heart disease, in whom background inflammation is already high. If TFAs exacerbate systemic inflammation in patients with heart disease, it would be important for secondary prevention efforts because the degree of systemic inflammation in these patients strongly predicts poor outcomes (5-8). To determine whether TFAs are related to systemic inflammation in patients with heart disease, we investigated the association between TFAs, as assessed with a biomarker of dietary intake, and systemic inflammatory markers in patients with established heart failure. Our hypothesis was that TFA levels would be associated with higher concentrations of inflammatory markers in these patients.

\section{SUBJECTS AND METHODS}

\section{Subjects}

This analysis was part of a prospective cohort study evaluating associations between clinical risk factors, inflammation, and disease severity among ambulatory patients with chronic heart failure. The patients were recruited from the end-stage heart failure clinic at the University of Washington Medical Center and were eligible if heart failure represented their greatest daily functional limitation in the judgment of the treating cardiologist. Exclusion criteria were a serum creatinine concentration $>3.0 \mathrm{mg} / \mathrm{dL}$, exercise-limiting chronic obstructive pulmonary disease, a severe psychiatric disorder, or a life expectancy $<12$ mo because of noncardiac disease. From April 1999 to April 2001, 150 patients met inclusion and exclusion criteria and agreed to participate. Demographics, clinical characteristics, and other risk factors were assessed at study visits with the use of standardized criteria. Measurement of red blood cell membrane fatty acids was added to the protocol after study initiation, when for 64 patients only serum samples (not containing red blood cells) had been stored; red blood cell membrane analysis was obtained in the remaining 86 patients, who form the cohort for this analysis. The study was approved by the Human Subjects Committee, and all participants gave written informed consent.

\section{Measurement of fatty acids and inflammatory markers}

Blood samples were drawn after placement of an intravenous line and 30 min of supine rest. Red blood cell membrane fatty acids were measured by gas chromatography (9), including measurement of 10 trans isomers: 2 of palmitoleic acid (7-trans-16:1 and 9-trans-16:1), 5 of oleic acid (12-trans-18:1, 11-trans-18:1, 10-trans-18:1, 9-trans-18:1, and a mix of 8-6 trans-18:1), and 3 of linoleic acid (9-cis, 12-trans-18:2, 12-cis, 9-trans-18:2, and 9-trans, 12 trans-18:2). Humans cannot synthesize TFAs, and red blood cell membrane TFA levels 
correlate with dietary TFA intake (9). Levels of these isomers were summed to determine total TFAs as a percentage of membrane fatty acids; we also separately evaluated the summed trans isomers of palmitoleic ( $t$-16:1), oleic ( $t$-18:1), and linoleic ( $t$-18:2) acids. Cytokines and inflammatory markers were assessed with potential prognostic importance in patients with established heart disease $(5-8,10)$. Blood for cytokine analysis was placed in glass tubes containing sodium fluoride and potassium oxalate (Becton Dickinson, Franklin Lakes, NJ), mixed, placed on ice, and centrifuged at $4{ }^{\circ} \mathrm{C}$ within 30 min of collection. Aliquots of plasma were stored at $-80^{\circ} \mathrm{C}$ until analyzed. C-reactive protein (CRP) and serum amyloid A (SAA) were determined by highly sensitive, nephelometric assays (Behring Diagnostics, Deer-field, IL and Liederbach, Germany), with lower limits of detection of 0.02 and $0.08 \mathrm{mg} / \mathrm{L}$ and CVs of 5-9\% and 4-8\%, respectively. Other inflammatory markers were measured with the use of enzyme-linked immunosorbent assay: in centralized laboratories at the University of Washington and Fred Hutchinson Cancer Research Center, with CVs from 5.7\% to 9.8\%, and reagents from R\&D Systems (Minneapolis), Biosource (Camarillo, CA), Pierce-Endogen (Rockford, IL), Monosan (Uden, Netherlands), Strategic Biosolutions (Ramona, CA), and Phoenix Pharmaceuticals (Belmont, CA) (Table 1) (11).

\section{Statistical analysis}

TFA levels were normally distributed; inflammatory marker concentrations were right-skewed and were $\log$ transformed before analysis. Linear regression was used to evaluate associations between TFA values and log-transformed inflammatory markers, with normality assumptions verified by using residual-versus-predictor plots. Parameters were identified as potential confounders if they might influence TFA intake or systemic inflammation and were then included as covariates in a multivariate linear regression model. Thus, the final model included age, sex, body mass index, New York Heart Association (NYHA) class, and ischemic etiology - each of which might influence either TFA intake or systemic inflammation-and smoking status, left ventricular ejection fraction, statin use, and serum glucose-each of which might influence systemic inflammation. For parsimonious modeling, other covariates such as race, education, income, other etiologies of heart failure, and other membrane fatty acid levels were not included in the final model because they were not prespecified potential important confounders and because their inclusion did not appreciably alter associations between TFA levels and most inflammatory marker concentrations. All $P$ values were two-tailed $(\alpha=0.05)$. Analyses were performed with the use of STATA 8.0 (Stata Corp, College Station, TX).

\section{RESULTS}

The mean $( \pm \mathrm{SD}$ ) TFA level was $1.8 \pm 0.4 \%$ of membrane fatty acids (range: $0.7-2.9 \%$ ), which was similar to that seen in other populations (9). TFA levels were inversely associated with male sex, former smoking, and membrane saturated fatty acid levels; there were also differences in age, NYHA class, ejection fraction, statin use, and fasting glucose, although these differences were not statistically significant (Table 2).

TFA levels were strongly associated with concentrations of several inflammatory markers. For each inflammatory marker, results are presented as the absolute difference and percentage difference from the mean for each $1 \%$ of membrane fatty acids from TFAs (approximately the difference between the first and third TFA tertile means). After adjustment for age and sex, TFA levels were positively associated with interleukin (IL) 1 receptor antagonist $(2129 \mathrm{pg} /$ $\mathrm{mL}, 157 \% ; P=0.02), \mathrm{IL}-10(218 \mathrm{pg} / \mathrm{mL}, 165 \% ; P=0.03)$, tumor necrosis factor $(\mathrm{TNF})$ receptor $1(463 \mathrm{pg} / \mathrm{mL}, 35 \% ; P=0.04)$, TNF receptor $2(24681 \mathrm{pg} / \mathrm{mL}, 155 \% ; P=0.003)$, monocyte chemoattractant protein $1(95 \mathrm{pg} / \mathrm{mL}, 98 \% ; P=0.003)$, and brain natriuretic peptide (41 pg/ $\mathrm{mL}, 58 \% ; P=0.02)$. Further adjustment for body mass index, smoking, ejection fraction, NYHA class, ischemic etiology, statin use, and serum glucose did not attenuate these 
associations; rather, the magnitudes of most of these associations were increased (Table 3 ). Additionally, TFA levels were now also positively associated with IL-1 $\beta(P=0.04)$, IL-6 $(P$ $=0.006)$, and TNF- $\alpha(P=0.02)$ and trended toward inverse associations with CRP $(P=0.05)$ and SAA $(P=0.06)$, although these latter relations were not statistically significant (Table 3$)$. TFA levels were not significantly associated with soluble IL-6 (sIL-6) receptor, IL-8, endothelin-1, or transforming growth factor $\beta$ (Table 3). Further adjustment for other patient characteristics, including other demographic factors such as race, education, and income; other etiologies of heart failure; and other membrane fatty acid levels did not appreciably alter most of the positive associations between TFA levels and inflammatory marker concentrations, although the relations with IL- $1 \beta$, brain natriuretic peptide, and SAA were in part attenuated (data not shown).

When we separately evaluated different trans isomers, $t-18: 1$ and $t-18: 2$ were, but $t-16: 1$ was not, consistently associated with higher inflammatory marker concentrations. For example, $t$-18:1 and $t$-18:2 levels (each $1 \mathrm{SD}$ ) were positively associated with IL-6 $(t-18: 1: 3.1 \mathrm{pg} / \mathrm{mL}$, $40 \%, P=0.006 ; t-18: 2: 2.6 \mathrm{~g} / \mathrm{mL}, 34 \%, P=0.029)$ and TNF- $\alpha(t-18: 1: 73 \mathrm{pg} / \mathrm{mL}, 71 \%, P=$ $0.016 ; t-18: 2: 69 \mathrm{pg} / \mathrm{mL}, 67 \%, P=0.038)$, whereas $t$-16:1 was not associated with IL-6 $(-0.2$ $\mathrm{pg} / \mathrm{mL},-3 \% ; P=0.83)$ or TNF- $\alpha(-27 \mathrm{pg} / \mathrm{mL},-26 \% ; P=0.17)$ (adjustments as in Table 3$)$.

\section{DISCUSSION}

Among patients with chronic heart failure, TFA intake assessed with a biomarker was strongly positively associated with several markers of systemic inflammation. The associations were seen after adjustment for a variety of demographic, clinical, and laboratory factors that might influence systemic inflammation.

We recently reported that TFA intake, as assessed with a food-frequency questionnaire, was associated with elevated TNF receptor concentrations among generally healthy persons (3). These observational findings were supported by the results of a short-term ( $5 \mathrm{wk})$ randomized trial in which TFA intake increased concentrations of several inflammatory markers, including e-selectin and IL-6, in 50 generally healthy men (4). The present study extends these prior findings by demonstrating strong positive associations between TFA levels and systemic inflammation in patients with established heart disease. The magnitudes of several of the associations are striking, including 2-fold to 4-fold higher concentrations of IL-1, IL-6, TNF receptor 2 , and TNF- $\alpha$ for each $1 \%$ of membrane fatty acids from TFAs. Notably, higher concentrations of these markers independently predict poor outcomes in patients with heart disease (5-8).

The observed associations do not prove causality; for example, it is possible that the degree of inflammation somehow influenced TFA levels, rather than TFA intake influencing inflammation. However, this would require a different physiologic relation between TFA intake, membrane TFA levels, and inflammation in patients with heart failure compared with other persons, because dietary TFA intake correlates with membrane TFA levels in healthy control subjects (9), positively relates to inflammation in healthy women (3), and increases inflammatory marker concentrations in healthy men (4).

There are biologically plausible mechanisms whereby TFA intake might increase systemic inflammation. TFAs are incorporated into endothelial cell membranes (12), which have numerous cell-specific pathways relating to inflammation (13). TFAs may also modulate inflammatory pathways via effects on macrophage membrane phospholipids and signaling pathways, analogous to mechanisms seen with n-3, n-6, and monounsaturated fatty acids (14). This hypothesis is supported by an experimental study among 19 subjects in which TNF production by cultured mononuclear cells was increased by a margarine diet (6.7\% of energy 
from TFAs) compared with a control diet ( $0.6 \%$ of energy from TFAs) (15). Proinflammatory effects of TFA intake might also explain other experimentally observed effects of TFAs. For example, TFAs increase insulin resistance, impair endothelial cell function, increase lipid oxidation, and reduce postprandial tissue plasminogen activator activity (16-19). Each of these abnormalities can be caused by inflammatory activation (20-23).

trans Isomers of oleic and linoleic acids but not of palmitoleic acid were associated with higher inflammatory marker concentrations. This finding is consistent with our prior observations among generally healthy persons, in whom intakes of $t-18: 1$ and $t-18: 2$, but not of $t-16: 1$, were associated with higher TNF receptor concentrations (3). Interestingly, in a population-based study, $t-18: 2$ levels were independently associated with a higher risk of primary cardiac arrest (9). Further investigation of the potentially different inflammatory effects of these different trans isomers is needed.

In the present study, TFA levels tended toward inverse associations with CRP and SAA. Of all the inflammatory markers, only CRP and SAA were positively correlated with body mass index (CRP: $r=0.40, P=0.0002$; SAA: $r=0.28, P=0.009$ ), which is inversely associated with heart failure mortality (24), consistent with catabolic metabolism predicting higher risk in this population (25). TFA intake increases CRP concentrations in generally healthy men (4) and is associated with higher CRP concentrations in generally healthy women with higher body mass indexes (3). Whether the different results of the present study for CRP and SAA are related to the potentially catabolic metabolism of heart failure patients or to some other factor is unknown, and further investigation of these potential differences is indicated.

Our study had some limitations. TFA intake was assessed with a biomarker, which may not perfectly capture dietary intake; such misclassification would bias results toward the null. Multiple comparisons increase the chance of type II error; however, TFA levels were positively associated with 9 of 15 inflammatory markers at $P<0.05$ and with 4 of 15 at $P<0.01$. Statistical power may have been inadequate to detect other relations, such as with sIL-6 receptor or transforming growth factor $\beta$. Potential residual confounding due to unmeasured or incompletely measured factors cannot be excluded, especially from other dietary factors that were not evaluated. On the other hand, the observed relations were independent of a variety of other factors known to affect systemic inflammation in heart failure, and, in our prior study (3), adjustment for other dietary factors did not greatly affect the results. The subjects in the present study were ambulatory heart failure patients, and findings may not be generalizable to other populations with established heart disease.

Our results suggest that TFAs are strongly associated with systemic inflammation in patients with chronic heart failure. This finding suggests a novel potential mechanism whereby TFA intake may affect the health of patients with established heart disease. Further study is indicated to investigate the potential proinflammatory effects of TFAs and the implications of such effects for secondary prevention efforts in patients with established heart disease.

\section{Acknowledgements}

DM was responsible for the conception and design of the study, for the data analysis and interpretation, for drafting the manuscript, and for the critical revision of the manuscript for important intellectual content. EBR was responsible for the data interpretation, and for the critical revision of the manuscript for important intellectual content. IBK, RLL, and GBM were responsible for the acquisition of data and for the critical revision of the manuscript for important intellectual content. WCL was responsible for the conception and design of the study, for obtaining funding, for the data interpretation, and for the critical revision of the manuscript for important intellectual content. The authors had no conflicts to disclose. 


\section{References}

1. Allison DB, Egan SK, Barraj LM, Caughman C, Infante M, Heimbach JT. Estimated intakes of trans-fatty and other fatty acids in the US population. J Am Diet Assoc 1999;99:166-74. [PubMed: 9972183]

2. US Department of Health and Human Services, Food and Drug Administration. Food labeling: trans fatty acids in nutrition labeling, nutrient content claims, and health claims. Internet: http:// www.cfsan.fda.gov/ acrobat/fr03711a.pdf (Federal Register, 68 FR 41433 July 11, 2003).

3. Mozaffarian D, Pischon T, Hankinson SE, et al. Dietary intake of trans-fatty acids and systemic inflammation in women. Am J Clin Nutr 2004;79:606-12. [PubMed: 15051604]

4. Baer DJ, Judd JT, Clevidence BA, Tracy RP. Dietary fatty acids affect plasma markers of inflammation in healthy men fed controlled diets: a randomized crossover study. Am J Clin Nutr 2004;79:969-73. [PubMed: 15159225]

5. Libby P, Ridker PM, Maseri A. Inflammation and atherosclerosis. Circulation 2002;105:1135-43. [PubMed: 11877368]

6. Kapadia S, Dibbs Z, Kurrelmeyer K, et al. The role of cytokines in the failing human heart. Cardiol Clin 1998;16:645-56. [PubMed: 9891594]

7. Rauchhaus M, Doehner W, Francis DP, et al. Plasma cytokine parameters and mortality in patients with chronic heart failure. Circulation 2000;102:3060-7. [PubMed: 11120695]

8. Blum A, Miller H. Pathophysiological role of cytokines in congestive heart failure. Annu Rev Med 2001;52:15-27. [PubMed: 11160765]

9. Lemaitre RN, King IB, Raghunathan TE, et al. Cell membrane trans-fatty acids and the risk of primary cardiac arrest. Circulation 2002;105:697-701. [PubMed: 11839624]

10. Pasic J, Levy WC, Sullivan MD. Cytokines in depression and heart failure. Psychosom Med 2003;65:181-93. [PubMed: 12651985]

11. Williams MA, Mahomed K, Farrand A, et al. Plasma tumor necrosis factor-alpha soluble receptor p55 (sTNFp55) concentrations in eclamptic, preeclamptic and normotensive pregnant Zimbabwean women. J Reprod Immunol 1998;40:159-73. [PubMed: 9881743]

12. Kummerow FA, Zhou Q, Mahfouz MM. Effect of trans-fatty acids on calcium influx into human arterial endothelial cells. Am J Clin Nutr 1999;70:832-8. [PubMed: 10539743]

13. Madge LA, Pober JS. TNF signaling in vascular endothelial cells. Exp Mol Pathol 2001;70:317-25. [PubMed: 11418010]

14. Grimble RF, Tappia PS. Modulatory influence of unsaturated fatty acids on the biology of TNF-alpha. Biochem Soc Trans 1995;23:282-7. [PubMed: 7672309]

15. Han SN, Leka LS, Lichtenstein AH, Ausman LM, Schaefer EJ, Meydani SN. Effect of hydrogenated and saturated, relative to polyunsaturated, fat on immune and inflammatory responses of adults with moderate hyper-cholesterolemia. J Lipid Res 2002;43:445-52. [PubMed: 11893781]

16. Christiansen E, Schnider S, Palmvig B, Tauber-Lassen E, Pedersen O. Intake of a diet high in transmonounsaturated fatty acids or saturated fatty acids. Effects on postprandial insulinemia and glycemia in obese patients with NIDDM. Diabetes Care 1997;20:881-7. [PubMed: 9135961]

17. Muller H, Seljeflot I, Solvoll K, Pedersen JI. Partially hydrogenated soybean oil reduces postprandial t-PA activity compared with palm oil. Atherosclerosis 2001;155:467-76. [PubMed: 11254919]

18. de Roos NM, Siebelink E, Bots ML, van Tol A, Schouten EG, Katan MB. Trans-monounsaturated fatty acids and saturated fatty acids have similar effects on postprandial flow-mediated vasodilation. Eur J Clin Nutr 2002;56:674-9. [PubMed: 12080409]

19. Lovejoy JC, Smith SR, Champagne CM, et al. Effects of diets enriched in saturated (palmitic), monounsaturated (oleic), or trans (elaidic) fatty acids on insulin sensitivity and substrate oxidation in healthy adults. Diabetes Care 2002;25:1283-8. [PubMed: 12145222]

20. Grimble RF. Inflammatory status and insulin resistance. Curr Opin Clin Nutr Metab Care 2002;5:5519. [PubMed: 12172480]

21. Bastelica D, Mavri A, Verdierl M, Berthet B, Juhan-Vague I, Alessi MC. Relationships between fibrinolytic and inflammatory parameters in human adipose tissue: strong contribution of TNF-alpha receptors to PAI-1 levels. Thromb Haemost 2002;88:481-7. [PubMed: 12353079] 
22. Bhagat K, Vallance P. Inflammatory cytokines impair endothelium-dependent dilatation in human veins in vivo. Circulation 1997;96:3042-7. [PubMed: 9386173]

23. Maziere C, Auclair M, Maziere JC. TNF enhances LDL oxidative modification by monocytes and endothelial cells. FEBS Lett 1994;338:43-6. [PubMed: 8307154]

24. Brophy JM, Dagenais GR, McSherry F, Williford W, Yusuf S. A multivariate model for predicting mortality in patients with heart failure and systolic dysfunction. Am J Med 2004;116:300-4.

[PubMed: 14984814]

25. Anker SD, Sharma R. The syndrome of cardiac cachexia. Int J Cardiol 2002;85:51-66. [PubMed: 12163209] 
TABLE 1

Methods for inflammatory marker analyses ${ }^{1}$

\begin{tabular}{|c|c|c|c|c|c|}
\hline & Capture antibody & Secondary antibody & Reference marker & $\begin{array}{c}\text { Lower } \\
\text { limit of } \\
\text { detection }\end{array}$ & $\begin{array}{c}\text { Median } \\
\text { value } \\
\text { and } \\
\text { normal } \\
\text { upper } \\
\text { limit }^{2}\end{array}$ \\
\hline IL- $1 \beta$ & $\begin{array}{l}\text { Biosource } \\
\text { AHC0013 }\end{array}$ & $\begin{array}{l}\text { Pierce-Endogen } \\
\text { M420B-B }\end{array}$ & $\begin{array}{c}\text { R \& D Systems } \\
\text { 201-LB }\end{array}$ & $0.2 \mathrm{pg} / \mathrm{mL}$ & $\begin{array}{c}0 \text { and } 0.6 \\
\mathrm{pg} / \mathrm{mL}\end{array}$ \\
\hline IL-1 receptor antagonist & $\begin{array}{l}\text { R \& D Systems } \\
\text { MAB280 }\end{array}$ & $\begin{array}{c}\text { R \& D Systems } \\
\text { BAF280 }\end{array}$ & $\begin{array}{c}\text { R \& D Systems } \\
280-\text { RA }\end{array}$ & $20 \mathrm{pg} / \mathrm{mL}$ & $\begin{array}{c}75 \text { and } \\
1210 \mathrm{pg} / \\
\mathrm{mL}\end{array}$ \\
\hline IL-6 & $\begin{array}{l}\text { R \& D Systems } \\
\text { MAB206 }\end{array}$ & $\begin{array}{l}\text { R \& D Systems } \\
\text { BAF206 }\end{array}$ & $\begin{array}{c}\text { R \& D Systems } \\
\text { 206-IL }\end{array}$ & $0.5 \mathrm{pg} / \mathrm{mL}$ & $\begin{array}{c}0 \text { and } 0.7 \\
\mathrm{pg} / \mathrm{mL}\end{array}$ \\
\hline Soluble IL-6 receptor & $\begin{array}{c}\text { R \& D Systems } \\
\text { MAB227 }\end{array}$ & $\begin{array}{c}\text { R \& D Systems } \\
\text { BAF227 }\end{array}$ & $\begin{array}{c}\text { R \& D Systems } \\
\text { 227-SR }\end{array}$ & $3.0 \mathrm{pg} / \mathrm{mL}$ & \\
\hline IL-8 & $\begin{array}{c}\text { Pierce-Endogen } \\
\text { M-801 }\end{array}$ & $\begin{array}{c}\text { Pierce-Endogen } \\
\text { M-802-B }\end{array}$ & $\begin{array}{l}\text { Pierce-Endogen } \\
\text { R-IL8-10 }\end{array}$ & $0.4 \mathrm{pg} / \mathrm{mL}$ & \\
\hline IL-10 & $\begin{array}{l}\text { Pierce-Endogen } \\
\text { M-010-E }\end{array}$ & $\begin{array}{c}\text { Pierce-Endogen } \\
\text { M-011-B }\end{array}$ & $\begin{array}{l}\text { R \& D Systems } \\
\text { 217-IL }\end{array}$ & $1.0 \mathrm{pg} / \mathrm{mL}$ & $\begin{array}{c}19 \text { and } 81 \\
\mathrm{pg} / \mathrm{mL}\end{array}$ \\
\hline TNF- $\alpha$ & $\begin{array}{l}\text { R \& D Systems } \\
\text { MAB610 }\end{array}$ & $\begin{array}{c}\text { R \& D Systems } \\
\text { BAF210 }\end{array}$ & $\begin{array}{c}\text { R \& D Systems } \\
\text { 210-TA }\end{array}$ & $1.5 \mathrm{pg} / \mathrm{mL}$ & $\begin{array}{c}0 \text { and } 12 \\
\mathrm{pg} / \mathrm{mL}\end{array}$ \\
\hline TNF receptor 1 & $\begin{array}{l}\text { R \& D Systems } \\
\text { MAB625 }\end{array}$ & $\begin{array}{c}\text { R \& D Systems } \\
\text { BAF225 }\end{array}$ & $\begin{array}{c}\text { R \& D Systems } \\
\text { 636-R1 }\end{array}$ & $2.0 \mathrm{pg} / \mathrm{mL}$ & $\begin{array}{c}662 \text { and } \\
925 \mathrm{pg} / \\
\mathrm{mL}\end{array}$ \\
\hline TNF receptor 2 & $\begin{array}{c}\text { R \& D Systems } \\
\text { AB226PB }\end{array}$ & $\begin{array}{c}\text { Monosan } \\
\text { MON9063B }\end{array}$ & $\begin{array}{c}\text { R \& D Systems } \\
226-B 2\end{array}$ & $15 \mathrm{pg} / \mathrm{mL}$ & \\
\hline TGF- $\beta$ & $\begin{array}{l}\text { R \& D Systems } \\
\text { MAB240 }\end{array}$ & $\begin{array}{l}\text { R \& D Systems } \\
\text { BAF240 }\end{array}$ & $\begin{array}{c}\text { R \& D Systems } \\
100-B\end{array}$ & $3.0 \mathrm{pg} / \mathrm{mL}$ & $\begin{array}{l}1840 \text { and } \\
9445 \mathrm{pg} /\end{array}$ \\
\hline MCP-1 & $\begin{array}{c}\text { R \& D Systems } \\
\text { MAB679 }\end{array}$ & $\begin{array}{l}\text { R \& D Systems } \\
\text { BAF279 }\end{array}$ & $\begin{array}{c}\text { R \& D Systems } \\
279-M C\end{array}$ & $4.0 \mathrm{pg} / \mathrm{mL}$ & \\
\hline BNP & $\begin{array}{c}\text { Strategic Bio } \\
\text { 9105M-01 }\end{array}$ & $\begin{array}{c}\text { Strategic Bio } \\
\text { 9105RA }\end{array}$ & $\begin{array}{c}\text { Phoenix Pharm } \\
011-03\end{array}$ & $\begin{array}{c}11.0 \mathrm{pg} / \\
\mathrm{mL}\end{array}$ & \\
\hline Endothelin-1 & $\begin{array}{l}\text { R \& D Systems } \\
\text { BBE5 }\end{array}$ & $\begin{array}{c}\text { R \& D Systems } \\
\text { BBE5 }\end{array}$ & $\begin{array}{l}\mathrm{R} \& \text { D Systems } \\
\text { BBE5 }\end{array}$ & $1.0 \mathrm{pg} / \mathrm{mL}$ & \\
\hline
\end{tabular}

${ }_{1} \mathrm{BNP}$, brain natriuretic peptide; IL, interleukin; MCP, monocyte chemoattractant protein; TGF, transforming growth factor; TNF, tumor necrosis factor. See text for locations of manufacturers.

${ }^{2}$ Where available, median and normal upper limit values (defined as the 90th percentile) were derived from 38 healthy adult volunteers aged $22-56 \mathrm{y}$, who were not taking antiinflammatory or immunosuppressive drugs and who provided blood in the morning under fasting conditions. 
TABLE 2

Patient characteristics according to trans fatty acid (TFA) concentration ${ }^{1}$

\begin{tabular}{|c|c|c|c|}
\hline & \multicolumn{3}{|c|}{ TFA tertile ( $\%$ of fatty acids) } \\
\hline & $1(1.4 \pm 0.2)$ & $2(1.7 \pm 0.1)$ & $3(2.3 \pm 0.3)$ \\
\hline No. of patients & 29 & 29 & 28 \\
\hline Age $(y)$ & $54.3 \pm 8.4^{2}$ & $52.8 \pm 9.9$ & $50.4 \pm 12.3$ \\
\hline Female sex $(\%)^{3}$ & 10 & 22 & 36 \\
\hline NYHA class 3-4 (\%) & 62 & 55 & 43 \\
\hline Ejection fraction (\%) & $30.5 \pm 8.0$ & $26.7 \pm 9.4$ & $26.1 \pm 11.5$ \\
\hline BMI $\left(\mathrm{kg} / \mathrm{m}^{2}\right)$ & $29.5 \pm 5.1$ & $30.3 \pm 6.6$ & $29.8 \pm 7.2$ \\
\hline Former smoker $(\%)^{3}$ & 66 & 69 & 43 \\
\hline Current smoker (\%) & 3 & 0 & 11 \\
\hline Idiopathic etiology (\%) & 41 & 55 & 50 \\
\hline Aspirin use (\%) & 38 & 45 & 39 \\
\hline ACE inhibitor/ARB (\%) & 97 & 100 & 100 \\
\hline$\beta$-Blocker $(\%)$ & 69 & 86 & 82 \\
\hline Statin $(\%)$ & 45 & 41 & 29 \\
\hline Total cholesterol (mg/dL) & $188 \pm 72$ & $184 \pm 41$ & $190 \pm 49$ \\
\hline Glucose (mg/dL) & $138 \pm 89$ & $120 \pm 42$ & $118 \pm 50$ \\
\hline Sodium (mEq/dL) & $137 \pm 5$ & $137 \pm 3$ & $137 \pm 2$ \\
\hline Creatinine $(\mathrm{mg} / \mathrm{dL})$ & $1.4 \pm 0.3$ & $1.2 \pm 0.3$ & $1.3 \pm 0.4$ \\
\hline Saturated fats ( $\%$ of fatty acids $)^{3}$ & $40.4 \pm 0.7$ & $40.1 \pm 0.6$ & $39.6 \pm 0.9$ \\
\hline Polyunsaturated fats ( $\%$ of fatty acids) & $35.1 \pm 1.1$ & $34.9 \pm 0.8$ & $35.1 \pm 0.8$ \\
\hline Monounsaturated fats (\% of fatty acids) & $18.4 \pm 1.1$ & $18.5 \pm 0.8$ & $18.5 \pm 1.0$ \\
\hline
\end{tabular}

${ }^{1}$ ACE, angiotensin converting enzyme; ARB, angiotensin receptor blocker; NYHA, New York Heart Association.

$2 \mathrm{x}^{-} \pm \mathrm{SD}$ (all such values).

${ }^{3} P<0.05$ for trend across tertiles. 
TABLE 3

Mean inflammatory marker concentrations and difference from the mean for each $1 \%$ of membrane fatty acids from trans fatty acids (TFAs) ${ }^{1}$

\begin{tabular}{|c|c|c|c|c|c|}
\hline & Concentration $^{2}$ & Partial correlation coefficient & $\begin{array}{l}\text { Difference } \\
\text { from mean } 3\end{array}$ & $\begin{array}{l}\text { Percentage } \\
\text { difference }\end{array}$ & $P$ \\
\hline & & & & $\%$ & \\
\hline $\mathrm{IL}-1 \beta(\mathrm{pg} / \mathrm{mL})$ & $0.57 \pm 0.08$ & 0.26 & 0.38 & 66 & 0.04 \\
\hline $\begin{array}{l}\mathrm{IL}-1 \text { receptor } \alpha(\mathrm{pg} / \\
\mathrm{mL})\end{array}$ & $1360 \pm 358$ & 0.34 & 4033 & 297 & 0.006 \\
\hline IL-6 (pg/mL) & $7.7 \pm 1.7$ & 0.35 & 9.5 & 123 & 0.006 \\
\hline $\mathrm{IL}-10(\mathrm{pg} / \mathrm{mL})$ & $132 \pm 32$ & 0.31 & 241 & 183 & 0.02 \\
\hline TNF- $\alpha(\mathrm{pg} / \mathrm{mL})$ & $103 \pm 30$ & 0.30 & 256 & 249 & 0.02 \\
\hline $\begin{array}{l}\text { TNF receptor } 1(\mathrm{pg} / \\
\mathrm{mL})\end{array}$ & $1322 \pm 91$ & 0.28 & 537 & 41 & 0.03 \\
\hline $\begin{array}{l}\text { TNF receptor } 2(\mathrm{pg} / \\
\mathrm{mL})\end{array}$ & $15880 \pm 4347$ & 0.43 & 39242 & 247 & 0.001 \\
\hline MCP-1 (pg/mL) & $98 \pm 19$ & 0.36 & 117 & 119 & 0.004 \\
\hline $\mathrm{BNP}(\mathrm{pg} / \mathrm{mL})$ & $71 \pm 7$ & 0.24 & 40 & \pm 57 & 0.04 \\
\hline $\begin{array}{l}\text { Soluble IL-6 receptor } \\
(\mathrm{pg} / \mathrm{mL})\end{array}$ & $14432 \pm 566$ & -0.18 & -1869 & -13 & 0.18 \\
\hline IL-8 (pg/mL) & $9.7 \pm 0.9$ & 0.09 & 2.2 & 23 & 0.33 \\
\hline Endothelin-1 (pg/mL) & $2.0 \pm 0.1$ & -0.10 & -0.18 & -9 & 0.42 \\
\hline TGF- $\beta(\mathrm{pg} / \mathrm{mL})$ & $13560 \pm 1306$ & -0.19 & -3855 & -28 & 0.17 \\
\hline CRP $(\mathrm{mg} / \mathrm{L})$ & $5.7 \pm 0.9$ & -0.23 & -2.7 & -48 & 0.05 \\
\hline SAA $(\mathrm{pg} / \mathrm{mL})$ & $9.0 \pm 1.8$ & -0.24 & -3.9 & -44 & 0.06 \\
\hline
\end{tabular}

${ }^{1}$ BNP, brain natriuretic peptide; CRP, C-reactive protein; IL, interleukin; MCP-1, monocyte chemoattractant protein 1; SAA, serum amyloid A; TGF, transforming growth factor; TNF, tumor necrosis factor.

${ }^{2}$ All values are $\mathrm{x}^{-} \pm \mathrm{SEM}$.

3 Differences are approximately those between the first and third TFA tertile means, adjusted for age, sex, BMI, smoking, ejection fraction, New York Heart Association class, ischemic etiology, statin use, and serum glucose. 